\title{
Assessment of the potential of tin sulphide thin films prepared by sulphurization of metallic precursors as cell absorbers
}

\author{
J. Malaquias ${ }^{1, a}$, P.A. Fernandes ${ }^{1,2, b}$, P.M.P. Salomé ${ }^{1, c}$ and A.F. da Cunha ${ }^{1, d}$
}

${ }^{1}$ I3N, Departamento de Física, Universidade de Aveiro, Campus Universitário de Santiago, 3810-193 Aveiro, Portugal

${ }^{2}$ Departamento de Física, Instituto Superior de Engenharia do Porto, Instituto Politécnico do Porto, Rua Dr. António Bernardino de Almeida, 431, 4200-072 Porto, Portugal

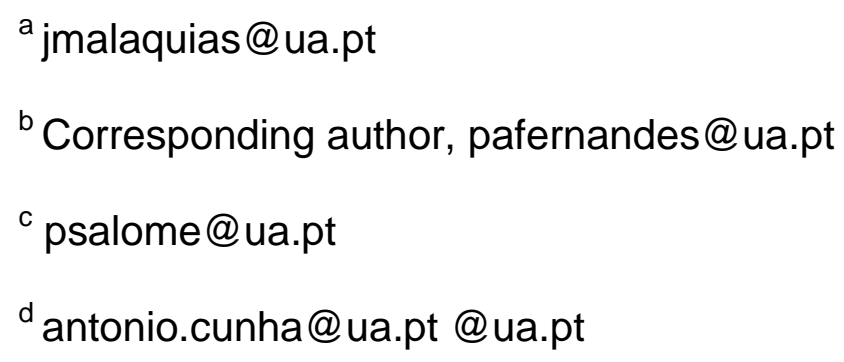

\section{Abstract:}

In this work, $\mathrm{Sn}_{\mathrm{x}} \mathrm{S}_{\mathrm{y}}$ (TS) thin films have been grown on soda-lime glass substrates by sulphurization of metallic precursors in a $\mathrm{N}_{2}+\mathrm{S}_{2}$ atmosphere. Different sulphurization temperatures were tested, ranging from $300^{\circ} \mathrm{C}$ to $520^{\circ} \mathrm{C}$. The resulting phases were structurally investigated by XRD and Raman spectroscopy. Composition was studied using EDS being then correlated with the sulphurization temperature. Optical measurements were performed to obtain transmittance and reflectance spectra, from which the energy band gap, were estimated. The values obtained were 1.16 $\mathrm{eV}$ for the indirect transition and for direct transition the values varied from $1.26 \mathrm{eV}$ to $1.46 \mathrm{eV}$. Electrical characterization using Hot Point Probe determined that all samples were $p$-type semiconductors. Solar cells were built using the structure: $\mathrm{SLG} / \mathrm{Mo} / \mathrm{Sn}_{x} \mathrm{~S}_{\mathrm{y}} / \mathrm{CdS} / \mathrm{ZnO}: \mathrm{Ga}$ and the best result for solar cell efficiency was $0.17 \%$. 
Keywords: Tin sulphide, sulphurization, thin film, solar cell

\section{Introduction}

The replacement of the $\mathrm{Culn}_{1-x} \mathrm{Ga}_{x} \mathrm{Se}_{2}$ (CIGS) as solar cell absorber by one that overcomes some of the difficulties has attracted the attention of several research groups in the last decade. The binary tin sulphide compound, $\mathrm{SnS}$, is a promising candidate which gathers two important advantages: it is relatively cheap and non toxic when compared with CIGS. The maximum efficiency attained so far for SnS based solar cells is $1.3 \%$ [1] which is a low value if compared with CIGS, 19.9 $\%$ [2]. Due to the increasing number of research group studying this compound it is expectable that this efficiency will increase further in the near future. Despite these advantages the SnS seem to be difficult to grow from raw materials due to the formation of spurious phase, such as $\mathrm{SnS}_{2}$ and $\mathrm{Sn}_{2} \mathrm{~S}_{3}$, during the sulphurization process. This difficulty is increased, especially for vacuum growth method, because SnS has a high vapour pressure which means that losses of material will happen for low processing pressures and temperatures.

Several methods have already been developed for the growth of $\mathrm{Sn}_{\mathrm{x}} \mathrm{S}_{\mathrm{y}}$. Conventional thermal evaporation and electron beam evaporation were tested by E. Ogah et al [3] and A. Tanusevski et al [4], respectively. K.T. Ramakrishna Reddy et al [5] were successful in growing SnS using dc magnetron sputtering of elemental Sn and post sulphurization process. Non vacuum methods have also been developed, namely chemical bath deposition technique by E Turan et al [6], spray-pyrolysis by K.T. Ramakrishna Reddy et al [1] and electro-deposition process by Shuying Cheng et al [7]. 
The aim of this work is to assess the potential of the binary tin sulphide compounds, $\mathrm{Sn}_{\mathrm{x}} \mathrm{S}_{\mathrm{y}}$, to be used as solar cell absorbers. Here we report the results of the growth and characterization of those compounds obtained by sulphurization of dc-magnetron sputtered elemental $\mathrm{Sn}$ precursor. Compositional and structural analyses were performed to identify and characterize the compounds that are grown. The influence of the maximum sulphurization temperature on the crystallization process is also investigated. The optical properties relevant for this study are the absorption coefficient (not shown) and band gap energy. The semiconductor conductivity type of the samples was analysed by Hot Point Probe. Solar cells were prepared with the structure $\mathrm{SLG} / \mathrm{Mo} / \mathrm{Sn}_{x} \mathrm{~S}_{\mathrm{y}} / \mathrm{CdS} / \mathrm{ZnO}: \mathrm{Ga}$ and characterized through I-V measurements.

\section{Experimental Details}

\subsection{Sample Preparation}

The method used in this work to grow the absorber layer can be divided in two stages [8]. First, an elemental Sn precursor layer is deposited by dc magnetron sputtering. The second stage is the formation of the $\mathrm{Sn}_{\mathrm{x}} \mathrm{S}_{\mathrm{y}}$ layer by sulphurization of the precursor in a programmable tubular furnace.

The $3 \times 3 \mathrm{~cm}^{2}$ soda lime glass (SLG) substrates are cleaned in successive ultrasound baths of acetone/alcohol/deionised water and later dried with a $\mathrm{N}_{2}$ flow. Next, the deposition of Mo back contact was performed by dc magnetron sputtering from a Mo target with purity $3 \mathrm{~N}$. In order to be able to perform transmission characterization, a mask was used to avoid the deposition of the Mo back contact in half the samples. Then, the metallic Sn precursor was deposited using dc magnetron sputtering. All depositions were done under an Ar atmosphere, at an operating pressure of $2 \times 10^{-3}$ mbar and power densities of $0.11 \mathrm{Wcm}^{-2}$. The purity of the Sn target was $4 \mathrm{~N}$. Initial thickness 
estimation was done based on the element molecular weight and bulk density. In situ monitoring was performed with a quartz crystal monitor.

The CZTS formation was performed in a tubular furnace in a $\mathrm{N}_{2}+\mathrm{S}_{2}$ vapour atmosphere at a constant working pressure of 5.0 mbar and a $\mathrm{N}_{2}$ flow rate of $40 \mathrm{ml} / \mathrm{min}$. Sulphur pellets with purity 5 $\mathrm{N}$, were evaporated at $130^{\circ} \mathrm{C}$ in a temperature-controlled quartz tube source. The furnace temperature was ramped up at $10{ }^{\circ} \mathrm{C} / \mathrm{min}$ to the maximum temperature. Different maximum sulphurization temperature were tested, $300 \stackrel{\circ}{\circ} \mathrm{C}, 340 \stackrel{\circ}{\circ} \mathrm{C}, 430{ }^{\circ} \mathrm{C}$ and $520{ }^{\circ} \mathrm{C}$. These temperatures were kept constant for 10 min and then the system was cooled down naturally.

For the solar cell preparation a CdS layer $50 \mathrm{~nm}$ thick was deposited on top of the $\mathrm{Sn}_{\mathrm{x}} \mathrm{S}_{\mathrm{y}}$ absorber by a chemical bath method. Finally a ZnO:Ga window layer $200 \mathrm{~nm}$ thick was deposited by RF sputtering.

\subsection{Characterization}

During the metallic precursor deposition in situ thickness measurement was done using a quartz crystal monitor. A Dektak 150 step profiler was used to measure the thickness of individual metallic precursors and the final $\mathrm{Sn}_{\mathrm{x}} \mathrm{S}_{\mathrm{y}}$ layer thicknesses. X-ray diffraction analysis was performed with a PHILIPS PW 3710 system equipped with a Cu-Ka source (wavelength $\lambda=1.54060 \AA$ ) and the generator settings were $50 \mathrm{~mA}, 40 \mathrm{kV}$. A Hitachi S4100 SEM and a Rontec EDS with setting parameters of $25 \mathrm{kV}$ and $10 \mu \mathrm{A}$ were used for compositional analysis. Raman scattering measurements have been performed at room temperature in the backscattering configuration and the excitation laser line used was $488 \mathrm{~nm}$. The Jobin-Yvon T64000 Raman spectrometer was equipped with an Olympus microscope with a 100x magnification lens. Optical measurements were done using 
a Shimadzu UV3600 spectrophotometer equipped with an integrating sphere. The majority carrier type was identified using a hot point probe system. The solar cell parameters have been estimated from the I-V curves measured with a home assembled I-V system under simulated standard illumination conditions. The sample naming scheme is according to the maximum sulphurization temperature.

\section{Results and Discussion}

Table 1 shows the results of the compositional analysis and the thicknesses for studied samples. This table shows a drop in Sn content of the sample with increasing sulphurization temperature from a near stoichiometric SnS at $300{ }^{\circ} \mathrm{C}$ to composition ratios close to 0.6 at $430 \stackrel{\circ}{ }{ }^{\circ}$. This value approaches the stoichiometric $\mathrm{SnS}_{2}$ composition. For higher temperature the results seem to stabilize at composition ratios of 0.7 . Analyzing the thicknesses, it is clear that for sulphurization temperatures of $430 \stackrel{\circ}{\circ} \mathrm{C}$ and $520{ }^{\circ} \mathrm{C}$ considerable material losses are observed, which is in accordance with the work published by P. A. Fernandes et al [9].

The figure 1 shows the XRD spectra for the samples sulphurized at $300{ }^{\circ} \mathrm{C}$, a), and at $340{ }^{\circ} \mathrm{C}$, b). For the lowest tested temperature, according to the International Centre for Diffraction Data (ICDD) [10], two compounds are identified: Herzenbergite $\mathrm{SnS}$ and $\mathrm{SnS}_{2}$. According to XRD analysis presented in figure $2 \mathrm{~b}$ ), increasing the temperature to $340{ }^{\circ} \mathrm{C}$, promotes the formation of a new compound, $\mathrm{Sn}_{2} \mathrm{~S}_{3}$.

The $X R D$ results of the samples sulphurized at $430 \stackrel{\circ}{C}$ and $520 \stackrel{\circ}{ } \mathrm{C}$ are shown in figure 2 a) and b), respectively. The spectrum for $\mathrm{S} 430$ shows that the sample is formed by a solid mixture of $\mathrm{SnS}_{2}$ and $\mathrm{Sn}_{2} \mathrm{~S}_{3}$. Unexpectedly no $\mathrm{SnS}$ phases were detected in this sample. The figure $2 \mathrm{~b}$ ) shows that for 
$520{ }^{\circ} \mathrm{C}$ the sample is formed by $\mathrm{SnS}$ and $\mathrm{SnS}_{2}$ phases. Comparing the XRD spectra of sample $\mathrm{S} 300$ and S520 it can be observed an improvement in the cristallinity of the compounds. In sample S520, the peaks seem to be sharper than for S300. In S300 the SnS phase appears to dominate over $\mathrm{SnS}_{2}$ while in S520 the opposite occurs.

Figure 3 shows the Raman scattering spectra of the samples sulphurized at $300^{\circ} \mathrm{C}$ a), $340^{\circ} \mathrm{C}$ b), $430{ }^{\circ} \mathrm{C}$ c) and $520{ }^{\circ} \mathrm{C}$ d). All these results confirmed the presence of $\mathrm{SnS}_{2}$ with a peak at $316 \mathrm{~cm}^{-1}$ [11]. Raman analysis detected SnS phases for samples S300, S340 and S520 with vibration modes located at $162 \mathrm{~cm}^{-1}, 193 \mathrm{~cm}^{-1}$ and $223 \mathrm{~cm}^{-1}$ [11]. The spectrum of sample S430, figure $3 \mathrm{c}$ ), show peaks at $237 \mathrm{~cm}^{-1}$ and $254 \mathrm{~cm}^{-1}$ which are assigned to $\mathrm{Sn}_{2} \mathrm{~S}_{3}$ [11]. Note that this compound also has a strong peak at $307 \mathrm{~cm}^{-1}$ [11], but for this sample it must be hidden by the $S_{n} S_{2}$ peak at $316 \mathrm{~cm}^{-1}$.

In figure 4 it is presented the results of the energy band gap estimation. These graphs show the values for direct allowed and indirect allowed transitions. It can be seen that for indirect transitions the value was independent of the sulphurization temperature and in the range to $1.16 \mathrm{eV}$ $1.17 \mathrm{eV}$ for all the samples. The estimation for direct transitions presents a decreasing value from $1.45 \mathrm{eV}$, for the lowest tested sulphurization temperature, $300 \stackrel{\circ}{\circ}$, to $1.26 \mathrm{eV}$, for temperatures of 520 ${ }^{\circ} \mathrm{C}$. This behaviour is due to the improvement in the cristallinity of the phases. Note that these values for both indirect and direct transitions refer to SnS phases, $[4,7]$. No influence of $\mathrm{SnS}_{2}$ phases were detected, which present an energy band gap above $2.0 \mathrm{eV}$ [13]. This result is due to the fact that in a solid mixture the optical behaviour of the material is ruled by the one with lower band gap energy. As a consequence, for the samples S340 and S430, a lower band gap value was expectable because of the presence of $\mathrm{Sn}_{2} \mathrm{~S}_{3}$ phases which have band gap close to $1.0 \mathrm{eV}$ [13]. Despite that no traces of $\mathrm{Sn}_{2} \mathrm{~S}_{3}$ phases were found in this analysis. 
Hot point probe analysis was performed for majority carrier identification and all the samples showed a p-type semiconductor nature.

In figure 5 the I-V characteristic of the best solar cell, sample S340, is presented. The cell performance parameters measured under simulated AM1.5 illumination were: open circuit voltage, $\mathrm{V}_{\mathrm{oc}}, 183 \mathrm{mV}$, short circuit current density, $\mathrm{j}_{\mathrm{sc}}, 2.7 \mathrm{~mA} / \mathrm{cm}^{2}$, fill factor, $\mathrm{FF}, 34 \%$ and conversion efficiency, $\eta$, of $0.17 \%$. The active area of the cell was $0.16 \mathrm{~cm}^{2}$. The other samples showed a much weaker photovoltaic effect.

\section{Conclusions}

This work describes a method to grow $\mathrm{Sn}_{\mathrm{x}} \mathrm{S}_{\mathrm{y}}$ compounds, using the sulphurization of an elemental Sn precursor, to be used as solar cell absorber. For all the growth conditions tested solid mixtures of $\mathrm{SnS}, \mathrm{SnS}_{2}$ and $\mathrm{Sn}_{2} \mathrm{~S}_{3}$ were obtained. Despite that, optical and electrical measurements showed that the influence of $\mathrm{SnS}_{2}$ and $\mathrm{Sn}_{2} \mathrm{~S}_{3}$ phases is small compared with the $\mathrm{SnS}$ phase. The band gap and majority carrier type is defined mostly by the latter phase. Adjustments in the growth conditions must be performed, namely in the sulphurization pressure and maximum temperature, in order to have a better control of the final composition of the films.

Preliminary solar cell work showed that the best results were obtained for the $\mathrm{Sn}_{\mathrm{x}} \mathrm{S}_{\mathrm{y}}$ films sulphurized at $340{ }^{\circ} \mathrm{C}$. The best cell efficiency was $0.17 \%$. Generally the cell parameters are low probably due to high recombination promoted by the presence of several phases and large density of grain boundaries. Furthermore in the preparation of the cells' window layer no i-ZnO was deposited which may have contributed to the observed low $\mathrm{V}_{\text {oc }}$. 


\section{Acknowledgements:}

P. A. Fernandes and P.M.P. Salomé thank the financial support of the Fundação para a Ciência e Tecnologia (FCT), through the PhD grant numbers SFRH/BD/49220/2008 and $\mathrm{SFRH} / \mathrm{BD} / 29881 / 2006$, respectively. FCT is also acknowledged for the financial support of the national electronic microscopy network, whose services we have used, through the grant REDE/1509/RME/2005.

\section{References:}

[1] K.T. Ramakrishna Reddy, N. Koteswara Reddy and R.W. Miles, Solar Energy Materials \& Solar Cells 90 (2006) 3041-3046.

[2] Ingrid Repins, M. Contreras, B. Egaas, C. DeHart, J. Scharf, C. Perkins, B. To and R. Noufi, Prog. in Photovolt:: Research and Applications, Volume 16, Issue 3 , Pages 235 - 239.

[3] Ogah E. Ogah, Guillaume Zoppi, lan Forbes, R.W. Miles, Thin Solid Films 517 (2009) 2485-2488.

[4] A. Tanusevski, D. Poelman, Solar Energy Materials \& Solar Cells 80 (2003) 297-303.

[5] K.T. Ramakrishna Reddy and P. Purandhara Reddy, Materials Letters 56 (2002) 108-111.

[6] E Turan, M Kul, A S Aybek and M Zor, J. Phys. D: Appl. Phys. 42 (2009) 245408 (6pp). 
[7] Shuying Cheng, Yanqing Chen, Yingjie He, Guonan Chen, Materials Letters 61 (2007) 14081412.

[8] P. A. Fernandes, P. M. P. Salomé and A. F. da Cunha, Thin Solid Films, (2009), 517, 2519-23.

[9] P. A. Fernandes, P. M. P. Salomé and A. F. da Cunha, Semicond. Sci. Technol. 24, (2009), 105013.

[10] International Centre for Diffraction Data - Ref. Code $\mathrm{SnS}_{2}$ 23-0677, SnS 33-1375, $\mathrm{Sn}_{2} \mathrm{~S}_{3} 72$ 0031.

[11] P. A. Fernandes, P. M. P. Salomé and A. F. da Cunha, "The importance of Raman analysis in the study of kesterites", to be published.

[12] P. A. Fernandes, P. M. P. Salomé and A. F. da Cunha, Phys. Status Solidi C 7, No. 3-4, 901904 (2010) / DOI 10.1002/pssc.200982746.

[13] A. Sanchez-Juarez and A. Ortíz, Semicond. Sci. Technol. 17 (2002) 931-937. 



\section{List of table captions}

Table 1: Composition ratios for the various samples. The thickness of the metallic precursor layers and the sulphurized samples. 


\section{List of figure captions}

Figure 1: XRD spectra of the sample a) S300 and b) S340. Peak assignment is made using data reported in reference [10].

Figure 2: XRD spectra of the sample a) $S 430$ and b) S520. Peak assignment is made using data reported in reference [10].

Figure 3: Raman scattering spectra of the absorber layer: a) sample S300; b) sample S340; c) sample S430 and d) sample S520.

Figure 4: Band gap energy estimation of the $\mathrm{Sn}_{\mathrm{x}} \mathrm{S}_{\mathrm{y}}$ samples S300, S340, S430 and S520.

Figure 5: I - V characteristics of the best solar cell, sample S340. 


\begin{tabular}{|c|c|c|c|}
\hline Sample & $\frac{[S n]}{[S]}$ & Sn thick. $(\mathrm{nm})$ & $\mathrm{Sn}_{\mathrm{x}} \mathrm{S}_{\mathrm{y}}$ thick.(nm) \\
\hline S300 & 0.98 & 1050 & 1580 \\
\hline S340 & 0.78 & 925 & 1580 \\
\hline S430 & 0.63 & 830 & 1280 \\
\hline S520 & 0.71 & 1400 & 750 \\
\hline
\end{tabular}

Table 1 

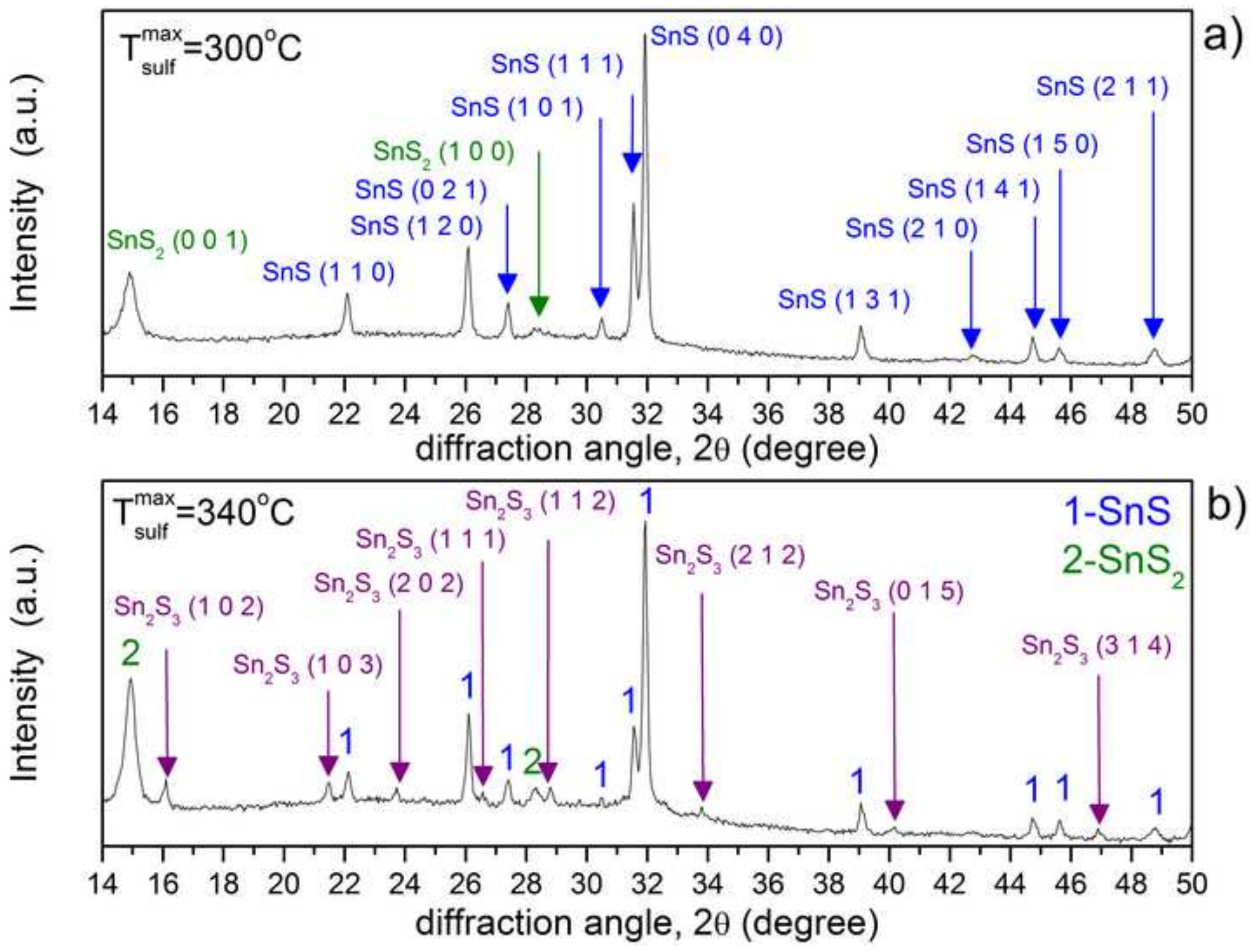


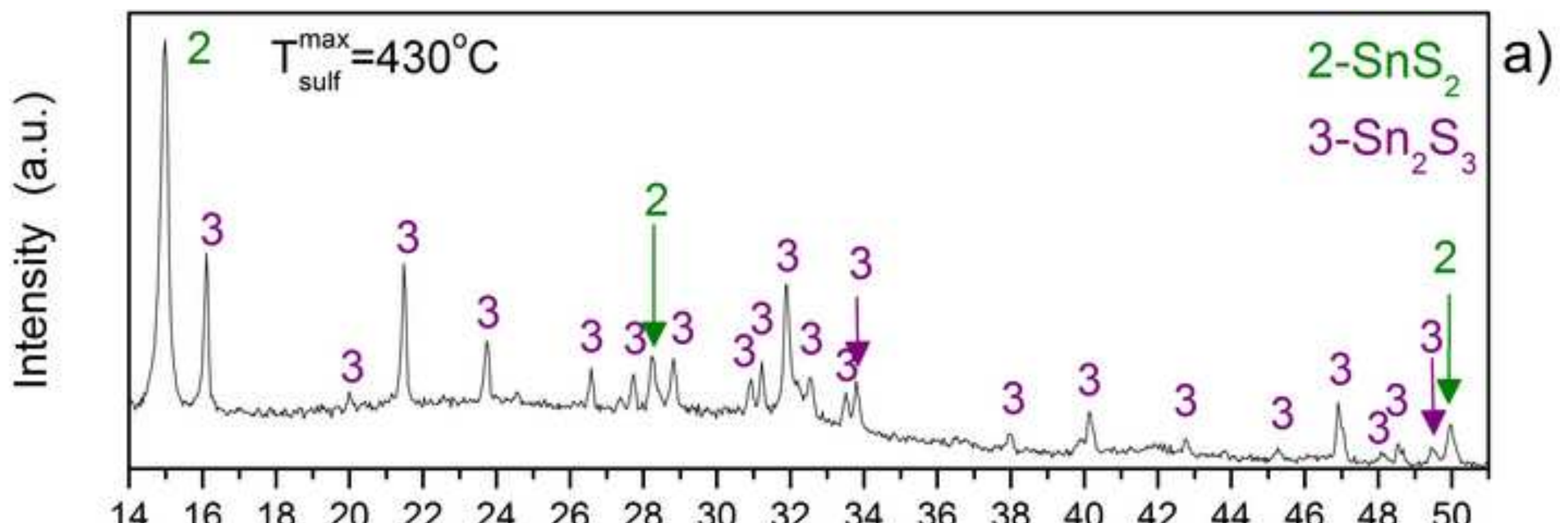

$\begin{array}{lllllllllllllllllll}14 & 16 & 18 & 20 & 22 & 24 & 26 & 28 & 30 & 32 & 34 & 36 & 38 & 40 & 42 & 44 & 46 & 48 & 50\end{array}$ diffraction angle, $2 \theta$ (degree)

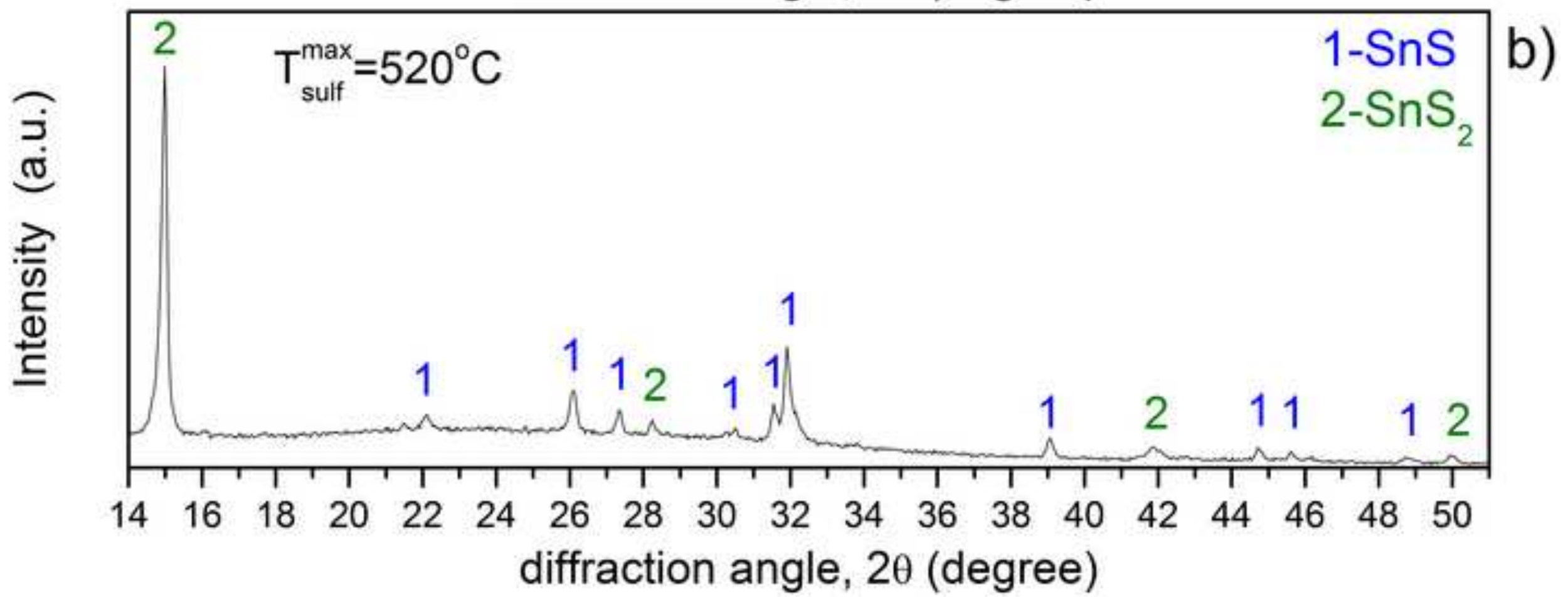



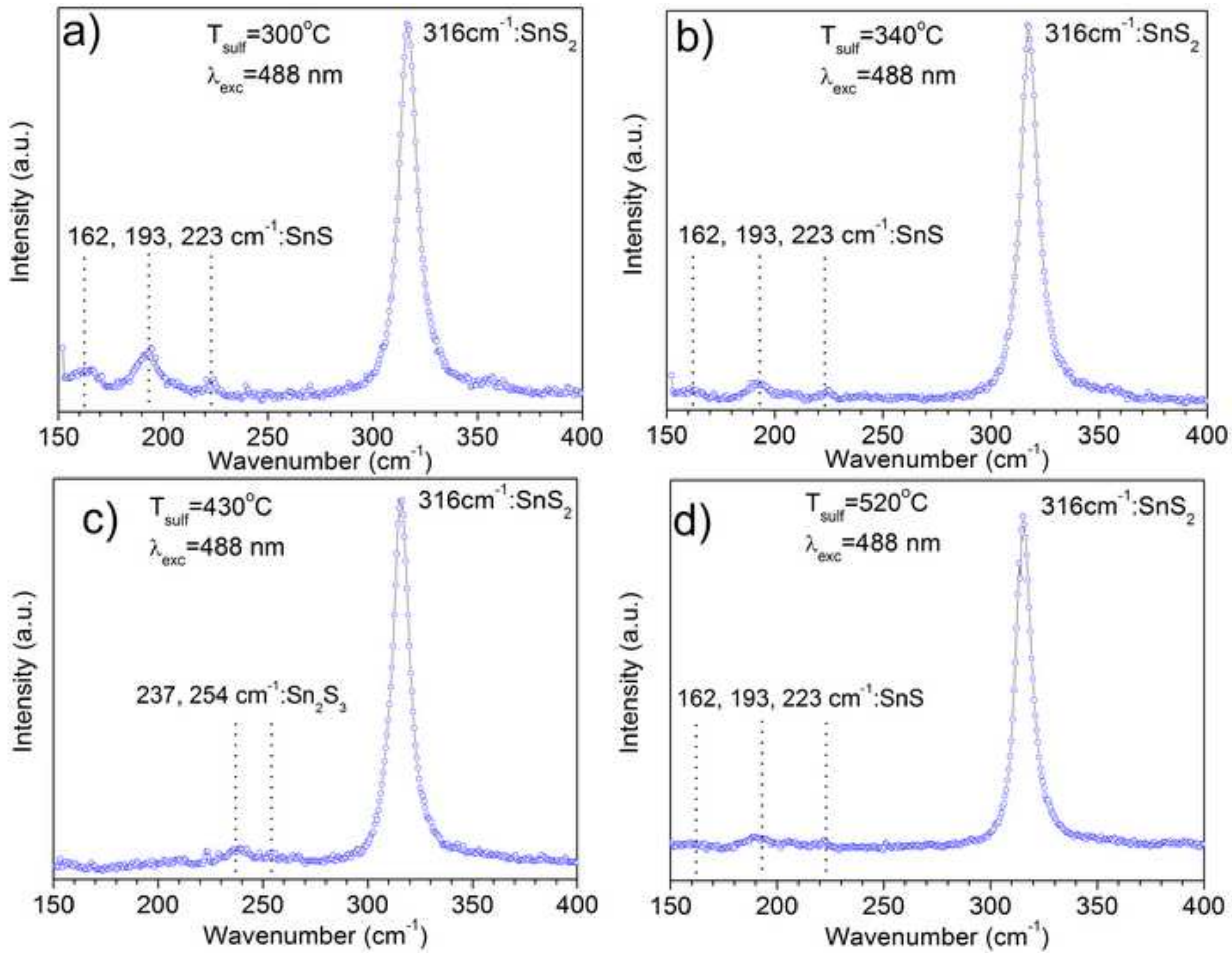

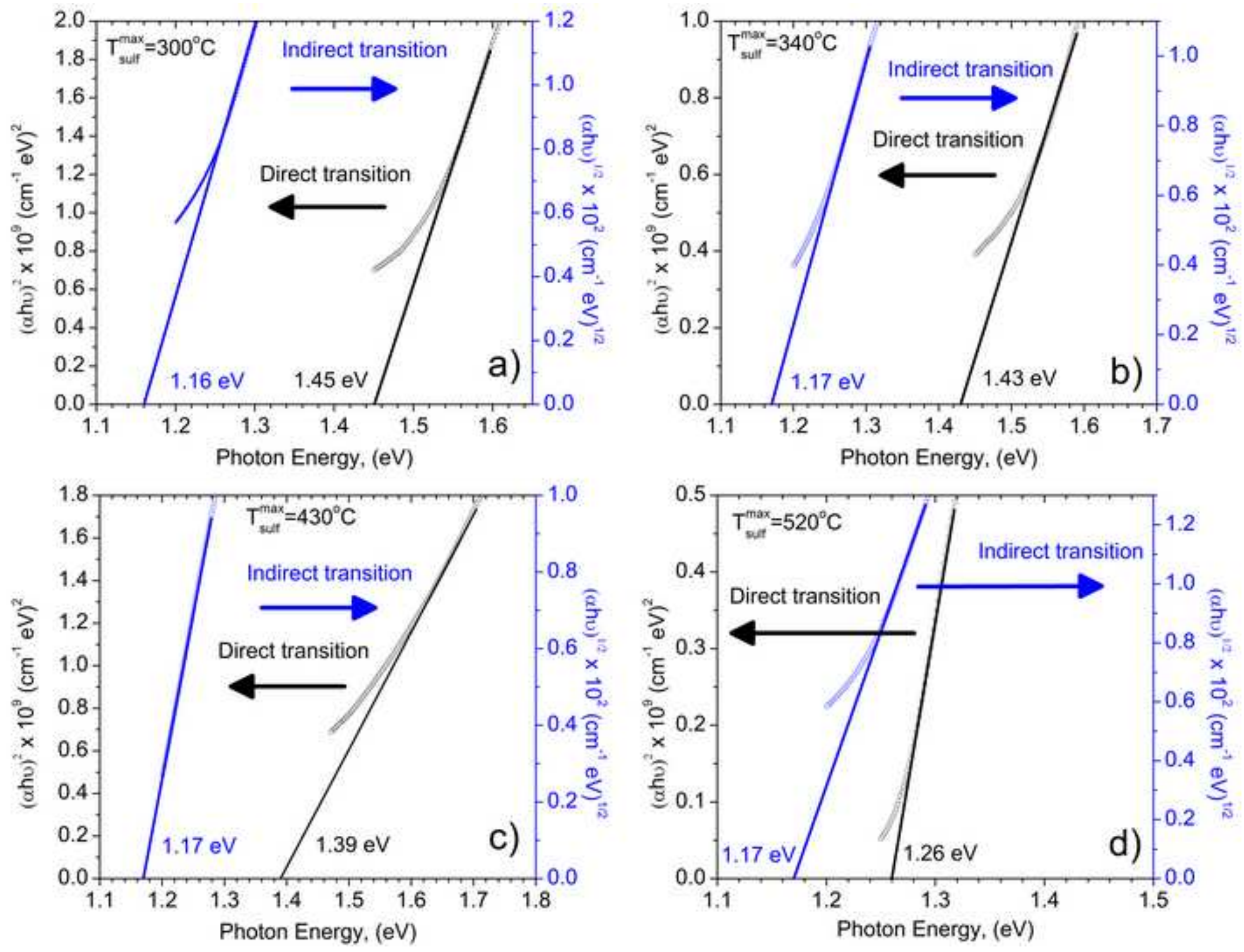


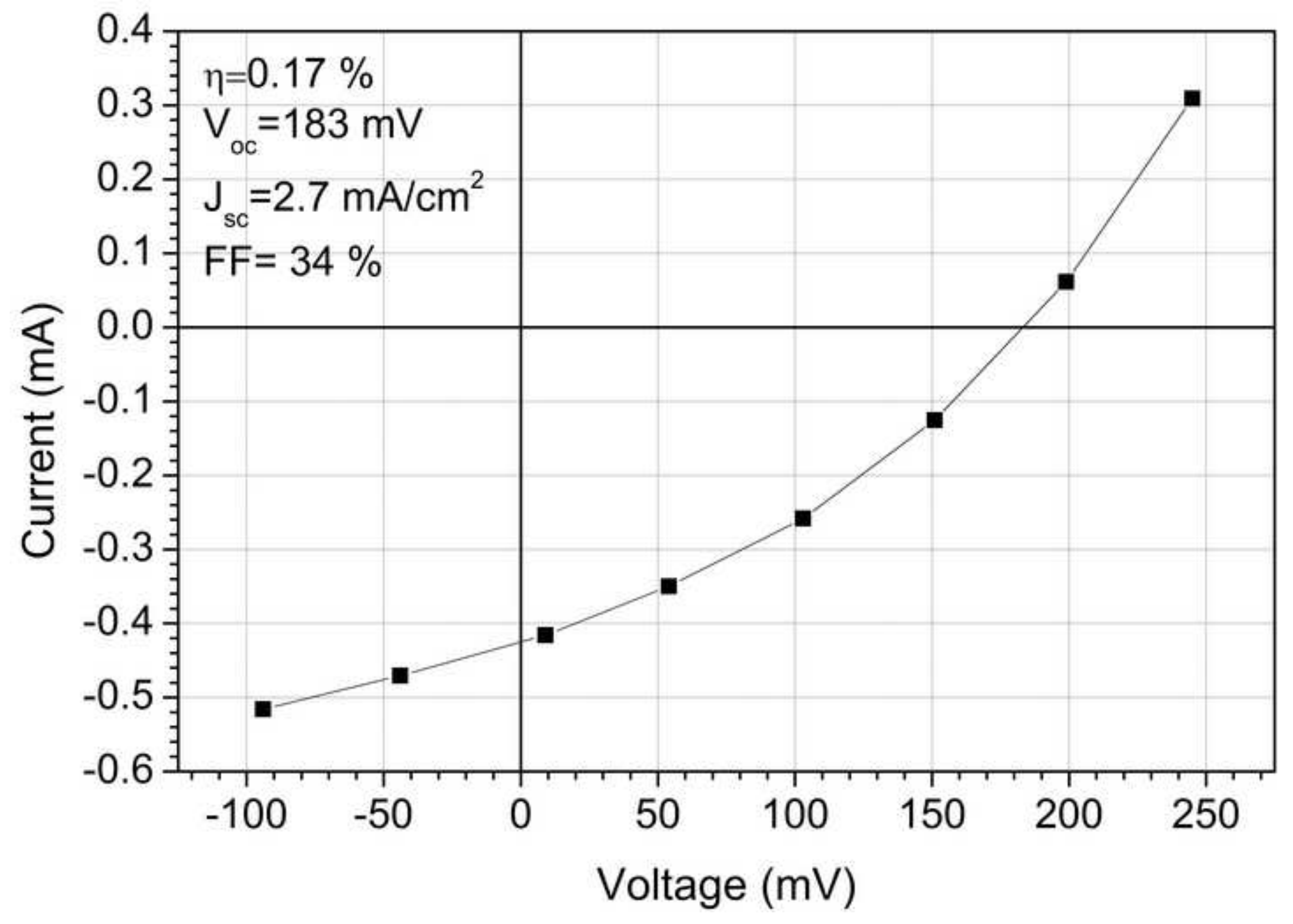

